\title{
ESTÉTICA Y TEORÍA DE LA SENSIBILIDAD EN EL PENSAMIENTO ANDALUSí'
}

\author{
José Miguel Puerła Vilchez
}

\section{RESUMEN}

Entendiendo la Estética en su sentido etimológico de «ciencia del sentir», el estudio de la teoría de la sensibilidad se convierte en indispensable para el conocimiento de una estética dada. Sin embargo, rara vez se han estudiado las teorías de la sensibilidad y del conocimiento en la cultura árabe islámica clásica en su dimensión estética, con lo que las conceptualizaciones difundidas acerca de la estética árabe e islámica suelen caer en la imprecisión y el juicio apriorístico. Aquí presentamos una aproximación a dicha temática a través de la obra de grandes pensadores andalusíes como Ibn Hazm, Ibn Bāŷŷa, Ibn Tufayl, Ibn Rušd, Hāzim alQartāŷannī, Ibn 'Arabī o Ibn Jaldūn, en cuya obra se aprecia una clara, aunque diversa, intención de configurar un sujeto humano perceptor y conocedor, ética y estéticamente definido, con psicologías y conceptos que más tarde hallaremos también en la construcción de la Estética en occidente.

Palabras clave: Estética árabe, Pensamiento andalusí, Al-Andalus-sentidos

\begin{abstract}
Understanding Aesthetics in it's etymological meaning as the «science of the perception» makes any study of the theory of the sensibility essential to understand a given aesthetics. Moreover, theories of sensibility and knowledge in Arabic and Islamic classical culture, have hardly been probed in it's aesthetic dimension. As a result of this, the spread of conceptualizations about Arabic and Islamic aesthetics has, in many cases, sunk in a sea of imprecisions and prejudgements. In the following pages, we present an approximation of these topics through works of greats thinkers from Al-Andalus such as Ibn Hazm, Ibn Bāŷŷa, Ibn Tufayl, Ibn Rušd, Ḥāzim al-Qarțāyannī, Ibn 'Arabī and Ibn al-Jaldūn, in whose works we appreciate a clear, though diverse, intention of constituting a cognizant and percipient human subject, ethically and aesthetically defined, across psychologies and concepts that we will also discover in the construction of Aesthetics in the West.
\end{abstract}

Keywords: Arabic aesthetic, Al-Andalus Philosophy, Al-Andalus-senses

1 Conferencia pronunciada el 25 de junio de 1998 dentro del Primer Curso de Historia y Cultura Medieval de Albarracín: Los cinco sentidos en al-Andalus, organizado por el departamento de Historia Medieval de la Universidad de Zaragoza y la Fundación Santa María de Albarracín (Teruel). El contenido del texto procede, en lo esencial, de temas tratados por extenso en diversas secciones de mi Historia del pensamiento estético árabe. Al-Andalus y la estética árabe clásica, Madrid, Akal, 1997. 


\section{INTRODUCCIÓN}

Entre aquellos que han exaltado, y exaltan, el carácter eminentemente sensitivo y sensual de la cultura árabe clásica, y entre los que ven en este presumible sensualismo árabe un lastre cultural o una prueba de su supuesto primitivismo, vamos a intentar aquí describir, en sus rasgos esenciales, la elaboración de una teoría de la sensibilidad en el pensamiento andalusí partiendo de las fuentes y volviendo siempre a los distintos contextos filosóficos en los que se fue creando una conceptualización del conocimiento prerracional, para evitar los juicios apriorísticos, idealistas, raciales y externos a los propios discursos árabes.

El tema, aunque relativamente poco estudiado hasta el presente a propósito de la cultura árabe, no así en lo que a occidente se refiere, tiene gran importancia tanto filosófica como estética y cultural, puesto que en él se ponen en juego algunos de los elementos fundamentales que conforman la creación del sujeto en la cultura árabe islámica clásica: la Revelación coránica, primero, más la subsiguiente labor exegética y, de manera muy especial, la falsafa y otras corrientes filosóficas, situaron al individuo en el centro del universo y se ocuparon de establecer las relaciones del mismo con la divinidad, la sociedad y la naturaleza, para lo cual desarrollaron sus respectivas teorías de la sensibilidad y del conocimiento en las que se dibuja cada vez con mayor nitidez, y pese a las tendencias más teologizantes, la figura de un sujeto pensante, artístico y éticamente responsable de sus actos. Existe aún un motivo más de interés para prestar atención a la teoría de la sensibilidad árabe, cual es el de la incidencia de la psicología elaborada en dicha tradición en la formación del campo conceptual de la estética - la ciencia del sentir - en la cultura prerenacentista y renacentista europea a través de las versiones latinas de al-Färābī, Avicena, Averroes e Ibn al-Haytam, ${ }^{2}$ sobre todo, con lo que dicha temática adquiere una importancia renovada para el historiador tradicional de la estética, cuya formación e intereses se circunscriben normalmente a la cultura curopea.

\section{LOS CINCO SENTIDOS EN LA CREACIÓN DEL SUJETO COGNOSCITIVO ÁRABE. LA APORTACIÓN ANDALUSÍ}

Se pueden establecer, esquemáticamente, dos ámbitos cognoscitivos en los que se desarrolla, en origen, una conceptualización de los sentidos, que son el ámbito de los textos sagrados y el ámbito del pensamiento filosófico, con las ramificaciones, interferencias y relaciones existentes dentro de cada uno y entre ambos a la vez. Habría que hablar también de los ámbitos de la literatura y las artes, pero eso ya es un tema que escapa con mucho a la presente exposición.

Los estudiosos de la poesía preislámica coinciden en señalar que se trata de una poesía que sitúa al ser humano como medida de las cosas en lugar de la divinidad y en que, salvo algunas escasas alusiones al monoteísmo, no hay apenas lugar en la casida preislámica para las ideas metafisicas. Estamos, por tanto, ante una estética construida a partir de imágenes sensibles, visuales sobre todo, relacionadas de forma inmediata con la naturaleza y, especialmente, con la figura femenina, 
que dejaría una profunda huella en toda la cultura árabe clásica ${ }^{3}$. El propio concepto de poesía (ši $r$ ) significa en árabe «conocer y/o sentir» a diferencia de nuestro concepto derivado, de poiesis, operar o producir.

En el Corán, los sentidos, la percepción sensorial y, en general, la estructura psicológica del ser humano, centro de la creación, son los instrumentos necesarios para recibir y comprender la verdad revelada. El vocabulario relacionado con los sentidos, el ojo, el oído, la ceguera, la sordera, la mudez, etc., repite figuradamente la idea de comprensión o no de la fe. Percibir es entender la palabra de Dios y el orden de su universo. El Corán apela continuamente al proceso de entendimiento (formas verbales de 'aqala), a la comprensión intelectual de la Verdad, pero se trata de una Verdad viva y activa que ofrece a través de sus símbolos un sentido palpable y sensorial de lo sobrenatural. Es la relación realidad-maravilla-sobrenatural que forma la ley de pertenencia del ser al mundo de lo creado, como ha dicho Mohammed Arkoun. ${ }^{4}$ En lo que a los placeres respecta, el Corán establece ciertas prohibiciones para fortalecer el espíritu del creyente, pero la licitud de los placeres físicos en el Libro es muy amplia y en los hadices, sobre todo, se defienden profusamente los goces sensoriales dentro de la moderación. Algunas aleyas coránicas proclaman, además, que Dios otorgó placeres al ser humano por su naturaleza de ser preferido entre los animales. ${ }^{5}$ Desde otro punto de vista, la riqueza de figuras literarias, ligadas sobre todo con lo visual, que abundan en el Libro pronto fueron objeto de atención por parte de la tratadística del $I \hat{y} a \bar{z} z$ que culminaría con `Abd alQähir al-Ŷyûâañ̂, quien teorizó sobre el carácter fuertemente sensitivo de las metáforas córanicas, con el intenso estupor estético que provocan, sobre la base de la profunda y especial unión entre los planos de la expresión y el contenido de la que hace gala sin igual el texto sagrado.

Así, cuando se desarrolla el pensamiento árabe islámico en suelo andalusí, existe todo un marco de referencia cultural sobre el tema de los sentidos que no se limita a la tradición poética árabe, a los textos sagrados y a las primeras controversias exégeticas de los mismos, sino que ya aparecen las primeras aportaciones propiamente filosóficas y, desde el s. VIII/IX, ya ha comenzado en oriente la adaptación e interpretación de parte del legado helenístico. En Al-Andalus, las primeras corrientes de pensamiento que se detectan tienen que ver con el mi tazilismo y con el espiritualismo de corte neoplatónico de Ibn Masarra y su escuela, al que más tarde haré alguna referencia, así como las diversas corrientes jurídicas, con el mālikismo a la cabeza, pero las figuras que van a centrar nuestra atención son, fundamentalmente, las de Ibn Hazm, Ibn Bā̂̂ya Ibn Tufayl, Ibn

3 A García Gómez todo este poso sensorial de la estética árabe, que atestigua en otros muchos ámbitos, como el Corán, los hadices, la poesía de Ibn Zaydūn, El collar de la paloma de Ibn Ḥazm, el Dēiūn al-\$ăbäba de Ibn Abī Hajala o hasta la mistica de Ibn al-Färid, le hace llegar a una conclusión inquietante: «el musulmán no puede desclavar de su alma la belleza, objetivándola ante sí como algo extraño. Está condenado a sufrir su yugo, y además, por no poder hacerla durar», mientras que el occidental sí se libera de la belleza sensible y la objetiviza en la obra de arte, a través de la pintu$\mathrm{ra}$, la escultura, etc. Y llega a exclamar: «en el reparto de los dones divinos, éste de la plástica le fué negado al Islam» («El sentimiento de la belleza físicas, en Cuadernos de Adán, 1 (1944), p. 94). En la introducción a su célebre versión del Collar de la paloma considera a lon Hazm «secuaz y víctima» de la presunta atracción irrefrenable de los árabes hacia las formas físicas (al-iftitän bi-l-swarar). Para una crítica de esta valoración, véase nuestra $H^{a}$ del pensamiento estético árabe, pp. $27-28$.

4 Arkoun, M., Al-Fikr al-islämi qirä’a 'ilmiyya, Beirut, Markaz al-Inmä’ al-Qawmī, 1987, capt. «Al-Aȳíb aljallāb fì l-Qư'ān», pp. 195-196.

5 Al-Zaydī, K. Y., Al-Tabt̆ a frl-Qurān al-Karm, Bagdad-Beirut,1980, pp. 215-221. Considera que en el Corán la vision no va separada del conocimiento (p. 95). 
Rušd e Ibn Jaldūn, más algunas referencias a otros sabios y retóricos como Ḥāzim al-Qarțâyannī y a la mística de Ibn 'Arabī, porque la teoría de la sensibilidad alcanza en ellos un desarrollo notable en su esquema del pensamiento y por la importancia de su obra en la historia de la filosofía árabe y universal. La diferente visión del mundo de cada uno de ellos hará más rico el contraste de sus teorias de la sensibilidad y del conocimiento y nos acercará al pensamiento árabe andalusí desde un ángulo no muy frecuentado por el historiador de la filosofía árabe e islámica, sino como momento residual y subalterno del resto de los discursos.

Ibn Hazm (994-1063), el gran teorizador del zāhirismo, trató de refundar las ciencas árabe islámicas sobre la base de la profunda coherencia del texto coránico y de su comprensión dentro de la evidencia significativa de la lengua árabe, evitando toda hermenéutica simbólica, subjetivista y mística. Por ello, desarrolló una concepción del alma humana muy particular que podemos calificar de eminentemente sensitiva. El alma hazmiana es una entidad corporal que impregna por entero el cuerpo humano y es la que posee la vida y la capacidad perceptiva y sensitiva del individuo: «No existe percepción sensible sin el alma (la hiss al-battata illa li-l-nafs), el único perceptor sensible (hassäs) es ella, es sensitiva aunque no se la sienta». ${ }^{6} \mathrm{La}$ define como la perceptora (mudrika) de todas las percepciones (mudrakāt), la que siente (hassāsa) todas las sensaciones (mahsüsăt), el dolor, el placer, la alegría, etc. Es el verdadero sujeto tanto de las sensaciones como de los sentimientos y las funciones intelectuales. Ibn Ḥazm elabora su concepción del alma partiendo de un sólido conocimiento de los textos sagrados, cuidando de que no entre en contradicción con ellos ni con su forma de interpretarlos. La percepción, tanto sensorial como lógica, del alma humana es innata. El alma percibe con los cinco sentidos (al-hawwäs al-jams) discerniendo (tamyizz), gracias a ellos, un aroma delicioso del que no lo es, así como las diferencias entre los colores y las cualidades táctiles, sonoras o térmicas de los objetos. Ibn Hazm añade una sexta percepción (al-idräk alsädis), que es la que enseña al alma las evidencias axiomáticas ( $a l-b a d i h a ̂ t)$, como que la parte es menor que el todo, etc., y que constituyen los principios de la razón ( $a q l$ ), que son comunes a todos los seres racionales. ${ }^{7}$ En Taqrïb señala la superioridad de la percepción racional (idräk al- aqql) sobre la percepción sensorial (idräk al-hawāss): los sentidos pueden errar, pero la parte racional del alma, sin relación con las imperfecciones de la materia, recompone la certeza del conocimiento. Aunque Ibn Hazm habla de potencias del alma (quwà $l$-nafs), como la opinión conjetural (zann), la fantasía (tajayyul), el pensamiento ( $f i k r)$ y la memoria ( $(i k r)$, lo cierto es que no desarrolla una psicología similar a los faläsifa y que su alma viene a ser una combinación directa de sensibilidad e intelectualidad. ${ }^{8}$ La razón actúa directamente con las percepciones sensibles descubriendo y rectificando al instante sus errores, mientras que la opinión conjetural y la fantasía son fuentes continuas de engaño. El uso de la razón, que es un deber impuesto por el Corán, es el único garante de la Verdad con la ayuda imprescindible de los sentidos. Como explicó Roger Arnaldez," lenguaje, percepción sensible y percepción racional han de coincidir cuando la operación del conocimiento

6 Ibn Hazm, al-Fișal fil l-milal wa-l-ahwä' wa-l-ni hal, Beinut, Där al-Fikr, 1980, V, p. 80.

7 Ibn Hazm, o.c., I, pp. 4*6. Cf. también su Fas̆l fi ma 'rifat al-nafs, en Rasä'il lbn Hazm, ed. de Ițān `Abbās, Beinut, al-Mu'assasat al-'Arabiyya li-l-Diräsăt wa-l-Našr, 1980-1983, I, pp. 443-446.

8 Ibn Hazm, al-Taqrib li-hadd al-mantiq, en Rasä'il lbn Hazm, IV, pp. 315-316.

9 Arnaldez, R., Grammaire et theologie chez Ibn Hazm, París, Vrin, 1981 (I $^{2}$ ed. 1956), pp. 106-116. 
es correcta: el zähir, la evidencia de la argumentación, consiste en la convergencia del zähir de los sentidos con el zähir de la lengua cuando ninguna pasión ni trastomo nos asalta, con lo que lbn Hazm logra presentar el carácter inapelable de la Revelación, tanto por la vertiente del lenguaje, como por la de los sentidos y la razón; lo demás es locura, impiedad o vano intento hermenéutico.

Con Ibn Bâyya (ca. 1085 ó 1090-ca. 1128 ó 1138) entramos en una perspectiva filosófica diferente, prácticamente nueva en al-Andalus, a saber, la falsafa o filosofía de tradición griega. Su teoría del alma, en la que hay que ubicar su teoría de la sensibilidad, se genera en un sistema epistemológico diferente que no se ocupa ya de problemas exegéticos, ni de la legitimidad del califato, sino que sus referencias políticas ideales están en Platón, Aristóteles y al-Fārābī. Ibn Bāŷŷa nos ofrece un esquema evolutivo del conocimiento que culmina con la sabiduría intelectual, girando toda su filosofía en tomo al camino de progresiva abstracción y elevación que debe seguir el individuo para transformar la sociedad imperfecta en una Ciudad Ideal donde sea posible la Felicidad Suprema. En su obra, la física aparece integrada en una perfecta unidad sin solución de continuidad con la metafísica. Ibn Bāŷa da una importancia primordial a la «ciencia del alma» de la que depende el conocimiento del mundo sensible y el ascenso al mundo espiritual superior, siendo la facultad fundamental del ser humano como centro del mundo y nexo entre el mundo físico y el metafísico. Ibn Bāŷỹa desarrolla, sobre todo, su teoría del conocimiento en su comentario a De anima de Aristóteles, que es el primer comentario sistemático de esta obra del Estagirita que conservamos en al-Andalus, y uno de los pocos existentes después del s. IX. ${ }^{10}$ Partiendo de la concepción aristotélica del alma como complemento vital del cuerpo en tanto que órgano mecánico, divide el alma en las siguientes facultades: nutritiva ( $g a ̈ d i y a)$, perceptiva (hassāsa), imaginativa ( $m u t a-$ jayyila) y racional (nätiqa). Las tres primeras son la perfección de la parte corporal mecánica y, la última, la potencia en la que se reúnen las formas elaboradas por todas las demás. Con su habitual método de referir los procesos anímicos a la dualidad motor-móvil, describe la percepción sensible como un fenómeno propio de los sentidos (hiss) en el que el motor es la percepción sensorial y el móvil, el órgano sensorial. A cada órgano le corresponde una percepción concreta, pudiendo estar los sentidos tanto en potencia como en acto, que es cuando pasan a percibir. Pero, ¿qué son las percepciones sensibles? La respuesta a esta pregunta clave abre la necesidad de explicar la materialidad o no de las formas sensibles y llevará a la postre a Ibn Bāŷya a detenerse en el fenómeno de la percepción visual como paradigma de toda percepción e, incluso, como fundamento previo de acceso al conocimiento. «Las percepciones sensibles son accidentes en cuerpos materiales, son propias de los cuerpos físicos, es decir, que se trata de las formas en los cuerpos físicos (suwar fi l-ầsäm al-tabF lyya)»." Las percepciones sensibles pueden ser primarias, como los colores (alwär), o secundarias, como las longitudes, las figuras $(a \bar{s} k a \hat{l})$ y las formas de las esencias físicas, perteneciendo todas ellas a la materia. Aquí se plantea la gran pregunta presente en toda la teoría del conocimiento árabe clásico: si las percepciones sensibles dependen necesariamente de la materia, ¿cómo

10 Parece que la primera versión de De anima al árabe es la de Istăc b. Hunayn (s. IX); al-Färäbĩ hizo otro comentario que no se conserva; segín al-Fihrist de Ibn al-Nadim, en esa época había versiones de Temistio y Simplicio de De anima disponibles en árabe; más tarde, contamos con la versión de lbn Sinãa (s. XI) y con la de lbn Rušd (s. XII).

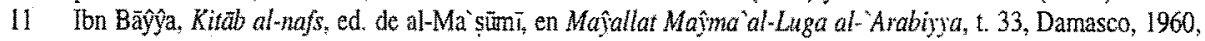
IV, capt. 3, p. 628. 
es posible que la percepción llegue a convertirse en forma separada (șüra mufäriqa)? Ibn Bäŷȳā responde recurriendo al concepto de ma nà, idea o concepto, la intentio de los medievales latinos, que define como la materia recibida espiritualmente. Es la idea o concepto de color, no la materialidad del mismo. La forma va unida inseparablemente a la materia, mientras que al-ma nà es «la forma aislada de la materia». ${ }^{2}$ Para Ibn Bāŷỹāla potencia perceptora (al-quwwa al-mudrika) no es una facultad trascendente, sino que está instalada en el cuerpo viviente, es más, la considera como la forma misma del temperamento humoral de los seres vivos, con lo que el temperamento y la conducta humanos quedan ligados de manera muy directa a los procesos de la percepción. ${ }^{13}$

En cuanto a Ibn Rux̌d (1126-1198), su peculiaridad estriba en que elaboró una teoría del conocimiento que concede una mayor dimensión que el resto de la falsafa a la sensibilidad en el proceso cognoscitivo y en las soluciones que ideó para explicar los fenómenos de la intelección dentro de la física y sin acudir a la metafísica iluminista. Lo primero que cabe destacar es que Ibn Rux̌d emprendió una reelaboración detallada de toda la psicología aristotélica, prueba de lo cual es que De anima fue una de las obras más comentadas (tres comentarios) y estudiadas por parte del filósofo cordobés. Para Ibn Rušd, igual que para Ibn Bāŷyā, la psicología se halla entre la física y la metafísica, pero Ibn Rušd se esfuerza en eliminar la confusión entre alma e intelecto y en reconducir lo metafísico hacia la estructura básica del conocimiento humano como individuo y como especie, con lo que las facultades sensitivas cobran en su sistema un papel fundamental. Él mismo clasificó el estudio del alma entre las obras físicas. Por ello, su teoría del alma, es decir, de la percepción y del conocimiento, se somete a los principios físicos de la relación potencia-acto, materia-forma y causa-efecto, a diferencia de la psicología avempaciana basada en la dualidad reposomovimiento y multiplicidad-unidad, con lo que su Talijş̣ Kitäb al-nafs resulta una obra bastante novedosa que muestra un espíritu más analítico que su modelo griego en la parte dedicada a los sentidos, y una gran originalidad en su análisis del intelecto. Entre ambos extermos, las facultades intermedias (sentido común, imaginativa, cogitatio) configuran una sensibilidad interna de la que dependen los procesos de la composición artística, poética y ética. El alma es, para Ibn Rušd, la forma y el perfeccionamiento del cuerpo físico y orgánico, y se compone de las siguientes facultades: vegetativa, sensitiva (al-nafs al-hassäsa), imaginativa (mutajayyila), racional (näțiqa) y apetitiva. ${ }^{14}$ El filósofo cordobés hace aquí un detenido examen del almā sensitiva, ${ }^{15}$ con las cinco fácultades sensoriales que la componen, donde trata de determinar con precisión cuál es la función judicativa de los sentidos. El interés de Ibn Rušd por este tema tiene raíz en su necesidad de fundamentar la posibilidad y necesidad del conocimiento sensible del orden de la realidad. Los sentidos perciben, en principio, de manera veraz, aunque les puede sobrevenir el error de modo accidental.

\footnotetext{
12 Ibn Bäŷya, o.c., V, pp. 120-121.

13 Ibn Bäŷya, oc.

14 Ibn Rušd, Taljü̦ Kitäb al-nafs, ed, de Salvador Gómez Nogales, Madrid, Instituto Hispano-Árabe de Cultura, 1985, p. 19.

15 El alma sensitiva es una potencia paciente que es actualizada por las percepciones sensibles (mahsüs $\bar{a} t$ ), las cuales son sensibles per se, como el color, el sonido, el aroma, etc., o sensibles comunes a más de un sentido, como el número, la figura, la magnitud, o sensibles per accidens, como distinguir que una persona es fulano y otra mengano, etc. La percepción sensible está a menudo amenazada de error, sobre todo la que depende de varios sentidos o la per accidens, por lo que habrá de recurrir a diferentes sentidos para establecer un adecuado discernimiento (tamyiz) (Ibn Rušd, o.c., pp. 41-42).
} 
La variedad de gustos no elimina la objetividad de la percepción, pero tampoco pueden identificarse totalmente sensibles y verdad, pues equivaldría a confundir sentidos (hiss) con intelecto ( $a q l$ ). La realidad externa y natural es objetiva, la percepción sensorial de la misma es veraz cuando el que percibe está sano y percibe en condiciones normales y adecuadas, es decir, cuando perceptor y objeto percibido se encuentran en su orden natural. La mentira hay que adjudicarla, por tanto, a la imaginativa. A cada sentido le corresponde una percepción concreta, y la variación de gustos depende de una alteración en el humor de quien degusta, por enfermedad, por ejemplo, o por alteración en la naturaleza del objeto degustado. Lo dulce puede pasar a ser amargo, pero si recobra su verdadera naturaleza será dulce. Si las cosas no tuviesen una naturaleza específica se imposibilitaría el propio conocimiento. ${ }^{16}$ El conocimiento sensible es, pues, posible y necesario, a pesar de las alteraciones de las condiciones y de los riesgos de error. De no ser así, no habría más que suposiciones y no realidades. En cuanto a los sentidos propiamente dichos, Ibn Rux̌d los diferencia en dos grupos:

1) el tacto (lams), el gusto (dawq) y el olfato (šmm), forman una sensibilidad primaria y su función se circunscribe al discernimiento, la averiguación de lo conveniente y la inferencia. Todos ellos perciben los ma äñ de sus respectivos sensibles, es decir, las intentiones o conceptos de los mismos, lo que representa un primer grado de abstracción. El tacto es un sentido peculiar: su instrumento perceptor está repartido por todo el cuerpo, percibe las cosas según la disposición (tartíb) que realmente tienen y es sumamente equilibrado, por lo que su capacidad de discernimiento (tamyiz) es mayor y más veraz, percibiendo contrarios, como lo pesado y lo ligero, en los que los demás sentidos yerran. El olfato, sin embargo, es muy débil en los humanos a diferencia de los animales, y la prueba es, señala Ibn Rušd, que denominamos los olores con los mismos nombres que los sabores (un dulce aroma, etc). El gusto es una especie de tacto, ya que percibe sus sensibles, los sabores, in situ, es decir, en el propio órgano sensorial, la lengua. Lo mismo le sucede, en su opinión, a la vista y al tacto, mientras que en el oído y el olfato sus sensibles están separados de sus sustratos.

2) el oído (sam') y la vista (ibṣär) tienen para Ibn Rušd un status especial, pues los considera sentidos al servicio de lo superior (min aŷli l-afdal), es decir, poseen funciones más allá de la estricta subsistencia. Después de definir en términos físicos, recurriendo a veces a antiguos como Temistio, las caraterísticas definitorias del oído, su medio, modo de transmisión, etc, menciona finalmente otras funciones superiores que lo ligan a facultades superiores como la imaginativa y el deseo ( sawa), cuales son la composición musical y el aprendizaje, que se produce a través del lenguaje y cuya comprensión es competencia de la razón intelectiva ( aql). En cuanto a la vista, ligada también a funciones estrictamente cognoscitivas, ocupa, como en tantos filósofos, el centro, de la teoría de la sensibilidad averroísta, y nos ocuparemos de ella en breve.

Después de establecer minuciosamente los presupuestos de la percecpión sensible, Ibn Rušd pasa al resbaladizo tema de la abstracción de los sensibles en el alma, y lo hace criticando las teorías precedentes desde la Antigiedad griega. La percepción no puede ser simple rememoración

16 El célebre optico oriental Alhacén (Ibn al-Haytam, ca. 965-1039), aristotélico y comentarista tambiến de $D e$ anima, aunque no se conserva su comentario, explicó en su famosa óptica (Kitäb al-manấịir) la naturaleza objetiva de la percepción visual, así como el tema de los errores visuales y sus consecuencias estéticas. 
(como pretende el platonismo), ni total materialidad, puesto que entonces sería físicamente imposible. La percepción requiere, necesariamente, intermedios entre los objetos y los sentidos, precisa también de los propios sentidos y los sensibles resultantes se imprimen en el alma, pero inmaterialmente. Los sentidos perciben los conceptos de los sensibles (ma'äni l-mahsüsät), con lo que no es la materialidad del color lo que llega hasta el alma, ni su idea previamente impresa en nosotros, sino los conceptos del color abstraído de la materia, que es lo que sucede con los demás sensibles. La percepción consiste en un proceso continuo de abstracción que va desde los particulares hasta los universales o inteligibles (ma qülät), teoría que el mismo lbn Rušd atribuye a Aristóteles. Conforme la inmaterialización de las formas es más sutil, la percepción será más completa y superior. Tomando como ejemplo la visión, Ibn Rux̌d establece tres niveles de formas, gradación que él mismo atribuye de igual modo a Aristóteles: 1) materiales, 2) la del sentido común, ya inmaterial y 3) la de la imaginativa, plenamente inmaterial. ${ }^{77}$ En este tercer nivel ya no se requiere la presencia de los objetos ante los sentidos. En esta teoría, la interdependencia y conexión entre sentidos, sentido común e imaginativa es muy fuerte, quizá más que en cualquier otro filósofo árabe. Supone, además, un conocimiento prerracional del que emerge el conocimiento estético, como el sabio cordobés lo explica al diferenciar la sensibilidad humana de la animal:

La prueba está en que las bestias no se motivan lo mismo que el ser humano a partir de estos sentidos, puesto que el ser humano se emociona ( $a$ trabu) al oír las melodías musicales ("inda samä al-alhän), pero no así las bestias (...). El ser humano se motiva también al ver figuras y colores pintados (yataharrak 'an ru'yat al-askäl wa-l-aşbăg) de una manera que no se da en los animales. Lo mismo sucede con muchas clases de sabores y olores, si bien los animales sí participan más de esto por su mayor corporeidad. Con la potencia del tacto sucede otro tanto, toda vez que la mano del ser humano tiene una especificidad que no la tiene ningún otro ser. El ser humano se orienta por el olfato sobre el sabor conveniente y el dañino, $y$ hasta se cura por medio de aromas y alimentos. ${ }^{18}$

Para Ibn Rušd, cada uno de los sentidos es, en el ser humano, un camino abierto hacia los inteligibles, pero de modo especial el oído y la vista, que ya Aristóteles los designó como los sentidos de más exacta capacidad de percepción y los más propiamente humanos. En su comentario a la Retórica, Ibn Rušd comentaba que ambos sentidos no son plenamente irracionales, sino que tienen cierta superioridad; atender a un relato, por ejemplo, es un placer elevado puesto que a un deleite intelectual se añade una sensación corporal que intensifica la impresión y la captación del mensaje. Es un placer que conlleva reconocimiento, o sea, la percepción de una relación entre las cosas. La pura sensibilidad interviene, pues, en la definición de las artes, en la fruición estética, ${ }^{19}$ pero

17 Ibn Rušd, Taljị̦ Kitab al-häss wa-l-mahsīos, en Aristūtuălis fi l-nafs, ed. de 'Abd al-Rahmān Badawī, KuwaitBeirut, Wikālat al-Maṭü àt-Där al-Qalam, 1980², pp. 202-203.

18 Ibn Rušd, o.c., p. 206.

19 Para Ibn Rušd el placer exige sensación, por lo que la imaginación, al conservar y operar con los sensibles, será la facultad esencial en la producción artística. Ademăs, el filósofo cordobés definía también el placer como la percepción de una sensación natural (ihsăs țabĩ i) para el perceptor, con lo que abunda, esta vez desde la sensibilidad, en el carácter de moderación y equilibrio de su estética. 
serán las facultades superiores las que completen tanto la teoría de la sensibilidad y de la abstracción formal, como los fenómenos de la producción poética y artística, nos referimos al sentido común y la imaginativa, los nexos necesarios y activos que ligan la sensibilidad y la racionalidad.

\subsection{Privilegio del sentido de la vista y teorías de la luz y el color}

Según hemos indicado, tanto la Revelación como el propio Aristóteles privilegiaban ya los sentidos de la vista y el oído, sobre todo el primero, como los canales principales de la percepción humana; en el primer caso, se apelaba al ser humano a través de dichos sentidos para que fuese testigo y comprendiese la perfección de la creación y del poder del Creador. En el caso del Estagirita estamos ante la definición del ser humano como sujeto cognoscente y, en tal esquema, los sentidos de la vista y el oído ocuparán un lugar determinante y eminentemente humanizador. Cuando pasamos la página hasta el pensamiento andalusí, nos encontramos con una situación básica similar, pero pronto aparecen los matices.

Ibn Hazm, en su teoria del conocimiento gobernada por un alma especialmente sensitiva, como decíamos, centra inmediatamente toda su atención en uno solo de los sentidos: la vista. Tanto en $a l$ Taqrīb li-hadd al-mantiq como en El collar de la paloma dice que los sentidos son puertas, ventanas o caminos abiertos al alma, "pero la vista (al-'ayn) es la más fiable y penetrante guía y la que actúa con mayor lucidez. Es conductora certera del alma, su dirección orientadora y su diáfano espejo en el que se le muestran las verdades, dicierne los atributos y comprende las percepciones sensibles. Se dice que lo que se cuenta no es como lo que se ve...». ${ }^{20}$ En Taqrib define cada sentido, pero sólo se detiene con detalle en la visión, llegando a decir que la percepción visual se compone de dos partes, la estrictamente ocular, que capta los colores, y la percepción que realiza el alma por el intelecto y el conocimiento completando la anterior con otros sentidos, con lo que su alma y su teoría del conocimiento van a ser, como veremos, fundamentalmente visuales. ${ }^{21}$ Gracias a los colores percibimos con inmediatez los elementos básicos del conocimiento, es decir, las figuras y las demás cualidades y estados de las cosas, su movimiento, reposo, etc. En el pensamiento de Ibn Hazm se asocian percepción visual e intelectual en el acto de conocimiento, que para él es ante todo «comprensión» ( $(\mathrm{h} h \mathrm{~h}$ ). El mundo de las formas es el delimitado por los colores, los cuales nos ofrecen los datos básicos para reconocer las cualidades (sifät) de las cosas e informar a nuestro intelecto. ${ }^{22}$ Su teoría de la percepción visual, expuesta en varias obras, puede sintetizarse así: 1) la realidad se percibe captando los colores de las cosas por medio de los rayos oculares que salen del ojo y se sitúan instantáneamente en cl objeto percibido y 2) existe, pues, una «luz ocular», que es lo que hace, precisamente, que la vista sea el más importante de los sentidos:

20 Ibn Hazm, Tâqq al -kamãnta, en Rasä̉il lbn Hazm, I, cap. 9 «Sobre las señales con los ojos», p. 137. El oído también tiene bastante importancia para Ibn Hazm para escuchar la palabra divina, la poesía clásica, las melodías, la comunicación, etc.

21 Ibn Hazm, Taqrib, pp. 157-158.

22 Dice, p. ej. que el movimiento no tiene color, pero que s6lo podemos percibirlo porque un objeto con color se mueve (Ibn Hazm, Fișal, V, p. 58). 
La excelencia de la vista consiste en que su esencia ocupa el rango más eminente y elevado entre todas las esencias, puesto que pertenece a la luz. La vista (basar) es imprescindible para percibir los colores. No hay nada que posea más alcance que ella, ni llegue más lejos, porque con ella se perciben los cuerpos de los astros que están en las lejanas esferas celestes (...); percibe tales cosas per saltum, sin recorrer etapas, ni detenerse en ciertos lugares, ni por transmisión de movimientos, cosa que no sucede con los demás sentidos, como el gusto o el tacto, que sólo perciben por contacto, o como el oído y el olfato, que sólo pueden percibir de cerca. ${ }^{23}$

Su teoría de la percepción es más sencilla que la de los falāsifa, privando a la razón de una sensibilidad intermedia elaborada: «La razón ( $a q l$ ) — dice Ibn Hazm - va asociada a todos los sentidos en sus percepciones, pero es ella sola la que nos informa de otras muchas cosas y la que percibe de manera global». ${ }^{24}$ Su teoría de las formas es, por ello, muy escueta también y siempre hulle de toda forma imaginaria, que para él es un impedimento o distorsión de la verdad. En su teoría de la percepción y del conocimiento el concepto de color se impone sobre el de forma, que es el imperante en la falsafa.

Aunque Ibn Hazm no desarrolló una teoría física experimental del nivel de Ibn al-Haytam (m. 1039) o de su comentador Kamāl al-Dīn al-Färisī (s. XIII-XIV), el tema del color ocupa un lugar importante en su pensamiento, por cuanto recurre a él profusamente a lo largo de su obra con un triple objetivo: lingüístico, lógico y sensorial. El color es su ejemplo preferido para definir las relaciones entre lafž y ma`nà (expresión y contenido), como también es su ejemplo recurrente al definir el concepto lógico de kayfiyy'a o qualitas y el de 'ardo accidente y, finalmente, el mundo de la percepción sensible se centra, como hemos dicho, en la percepción visual y ésta en el color, que resume para él la forma de los objetos de la realidad sensible. Estos tres niveles, el del lenguaje, el de la razón lógica y el de la sensibilidad, han de coincidir siempre en el pensamiento de Ibn Hazm. No puede haber contradicción entre ellos, y los tres se explican mutuamente.

Lingüística y lógicamente, al-lawn (el color) es un nombre genérico y cada una de sus especies (rojo, blanco, verde, etc.), tiene a su vez numerosos particulares, es decir, hay clases de rojo, de verde, etc. Esto hay que aplicarlo a la interpretación de los textos sagrados y del mundo.

El mundo se compone de Creador y creación, y esta última de cuerpos o sustancias (que para él son sinónimos) y accidentes. Los colores son accidentes, con la importancia especial de que nos informan sobre la realidad de los cuerpos.

Su teoría de la visión consiste, en resumen, en la percepción de los objetos y de sus cualidades y circunstancias a través de la captación de los colores de las cosas, y se lleva a efecto por los rayos visuales que salen del observador y tocan la materia iluminada. Los colores ${ }^{25}$ se estructuran

23 Ibn Hazm, Tawq al-hamäma, p. 138.

24 Ibn Hazm, Taqrib, p. 161.

25 Ibn Hazm desarrolla su teoría del color en un capítulo inconcluso e insertado en el Fisal sin relación aparente con el contexto teológico de la obra: Fisal, V, pp. 136-140, tr. de Asín Palacios, Abenházan de Córdoba y su historia crítica de las ideas religiosas, Madrid, Turner, 1984, V, pp. 362-369; sobre reflexiones léxicas y lógicas sobre el color, cf. alIhkām fĩ ușül al-ahkām, ed. de Aḥmad Muhammad Šākir, Dār al-Afãq al-Ŷadīda, 1980, III, pp. 3-4, 63-64, y Taqrỉb, pp. 154-156. 
en una gradación tonal que va desde el negro, como no color y carente de luz, hasta el blanco, que reúne todos los colores y que, al igual que la luz, forma parte de los mismos: amarillo, rojo, verde, azul y violeta, más sus posibles mezclas en las que sí puede intervenir el negro, aunque no explica cómo. Se preocupa, sobre todo, de demostrar que el negro no es un color, sino la oscuridad o la falta absoluta de color: es el anticolor. Captamos el negro porque los rayos visuales se topan con colores que, a veces, delimitan una zona sin color que los rayos oculares no pueden aprehender y nos da la sensación de negrura. El brillo y lo mate son también colores, pues, en caso contrario, no los veríamos. Para Ibn Hazm la luz, que no estudia como tal, es equiparable al color blanco y posee la función de dilatar tanto los rayos visuales como los propios colores, posibilitando la percepción de los mismos, cuya variedad depende de la intensidad de su iluminación. Tanto el exceso como la falta de luz son negativos para la visión. Los colores son para él accidentes de gran importancia, puesto que nos informan sobre los objetos y sobre otros accidentes como el movimiento, las dimensiones, etc. esenciales para el conocimiento y para la percepción estética. La percepción para Ibn Hazm es una suerte de tacto, puesto que del ojo surgen, y a él regresan, los rayos oculares, que, como prolongación del sujeto que mira y de su alma que siente, palpan el mundo y lo conocen. Sólo la oscuridad, la luz cegadora o una enfermendad, además del sueño y la imaginación, interrumpen nuestra percepción directa y objetiva de la realidad. El color, en su íntima fusión con la luz, que es la que revela los colores y la que, así, da vida a los objetos y al propio órgano de la visión dilatándolo, es algo más que una luz accidental que recubre el objeto, se trata, en realidad, del accidente fundamental que define las cosas y la fuente primordial que permite el conocimiento del mundo sensible en interacción con las facultades del alma. El concepto de lawn, color, que puebla los libros del gran alfaquí cordobés ocupa el zăhir o manifestación evidente del mundo natural, en paralelo con el concepto de lafz̧ o zähir del nivel lingüístico y del mundo conceptual del lenguaje. Tanto el color como la palabra son la luz que nos informa de manera directa y precisa sobre el mundo, las ideas y la Revelación y, también, sobre la belleza en todas sus modalidades: física, ética y espiritual.

Ibn Bāŷŷa también concede a la visión una importancia especial en su teoría de la percepción y, dentro de ella, a la teoría de la luz y el color, sobre las que da algún punto de vista original. ${ }^{26}$ Define la potencia visual (quwwat al-basar) como «el perfeccionamiento primero del órgano ocular; es el alma visora (al-nafs al-bāsirira)...». ${ }^{27} \mathrm{El}$ paso, en esta potencia, del estado potencial a la sensación, tiene como protagonista al color, cuya problemática ocupa casi toda la teoría de la percepción visual de Ibn Bāŷŷa. La visión es la potencia existente en el ojo con la que éste percibe el color, dice el filósofo zaragozano, y se encuentra en la humedad ocular. Para entender la visión hay que entender, por tanto, el color, e Ibn Bāŷŷa pasa a exponernos su particular teoría del color: 1) el color sólo puede ser percibido en un medio atmosférico; 2) la atmósfera contribuye a que la vista perciba el color sólo en presencia de la luz. Los colores existen en la oscuridad y su visión depende del medio y de la luz; he aquí, en síntesis, su teoría de la luz:

26 Hay que advertir que conocemos los títulos de tres tratados sobre óptica y geometría compuestos por Ibn Bāŷya

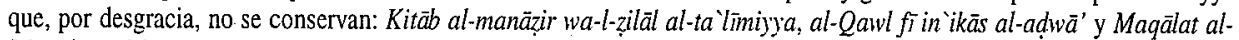
Iskandar fi l-lawn wa-ayy săgy' huwa 'alà ra'y Aristū, con lo que la teoría de la visión de Ibn Bāŷya debió de ser bastante más rica y precisa que lo que muestran sus obras conservadas.

27 Ibn Bāŷŷa, Kitäb al-nafs, VI, capt. 4, p. 332. 
a) define la luz como «lo que hay en la atmósfera cuando se hace presente un cuerpo en la situación de estar iluminado»; 28

b) la iluminación se produce por un foco de luz que incrementa la luminosidad de un cuerpo dado, de donde se comprueba que la luz se propaga de modo inmediato, sin mediación de tiempo alguno;

c) como señaló Henri Corbin, Ibn Bāŷya ofrece aquí una teoría original: «puesto que el color se produce, según se explica en al-Hiss wa-l-mahsüs (De sensu et sensibili de Aristóteles), al unirse lo iluminado con un cuerpo provisto de color, el color será también, de alguna manera, luminoso y motor del aire». ${ }^{29}$. Color y cuerpo iluminado se movilizan recíprocamente, así como luz y color van inseparablemente unidos. El color mueve al medio transparente, dice Ion Bâŷŷa, por lo que la visión no se produce en el vacío, el medio es imprescindible, sea el aire o el agua. La luz suscita el color y el color, a su vez, suscita al medio, por lo que luz, color y medio conforman un triángulo compacto e indisociable en la teoría de la visión avempaciana;

d) la imagen especular es diferente de la imagen visual: en el órgano ocular, los ma`ānīo intentiones de las imágenes sensibles toman cuerpo, se imprimen, y entran a formar parte de los procesos psicológicos, no así en los espejos, que sólo se reflejan y no se imprimen perdurablemente.

En esta perspectiva, el color es fundamental: existe per se, aunque necesite de la luz para hacerse visible; la luz no se entiende sin el color y la combinación luz-color es la que suscita el medio transparente y la que posibilita la percepción espacial; los colores hacen, además, que el sentido común retenga mejor las formas percibidas, lo que explica, para él, que el aspecto visual de las cosas sea más placentero que su propia utilidad práctica, pues dicho aspecto está más ligado al mundo material, lo que lo expone, a la vez, a los riesgos de caer en el vicio y alejarse de los fines elevados.

Ibn Bāŷŷa dedica también cierta atención a la audición. La define como la percepción de la huella que deja en el aire la colisión entre dos cuerpos, y lùego menciona otras características físicas del fenómeno, para más tarde definir el sonido melódico (nagma) como la acumulación de percusiones en el aire producidas por instrumentos musicales, como el laúd. Las melodías pueden ser armónicas y disarmónicas, aunque, por desgracia, no desarrolla más el tema, pues dice que ya lo hizo en otras obras. Los biógrafos de Ibn Bāŷŷa lo consideran poeta y músico, pero su obra musical se ha perdido. Nos queda, sin embargo, un breve fragmento sobre los valores propedéuticos de las melodías musicales. Su argumento central, en este tema, no es nuevo, y se funda en la idea de que la música es capaz de influir en el temperamento humano gracias a la sincronía o concordancia que supuestamente existe entre los diversos caracteres temperamentales y los sonidos del laúd. La idea se difundió al menos desde al-Fārābī y fue rebatida con ahínco por Ibn Hazm. La premisa clave que explica la incidencia directa de los sonidos del laúd en la psique del receptor es la afinidad (munāsaba) existente entre cada una de las cuerdas del laúd y cada uno de los cuatro tipos humanos: colérico, sanguíneo, flemático y melancólico. El sonido de cada cuerda del laúd duplica 
en intensidad acústica a la cuerda precedente, lo que posibilita, a su parecer, que entren en armonía con cada uno de los temperamentos humanos señalados. ${ }^{30}$

Ibn Rušd, por su parte, también dedica la mayor atención, dentro de su teoría de la sensibilidad, a la temática de la percepción visual, tanto en su comentario a De anima como en el comentario a De sensu. Su definición de la potencia visual es algo diferente y acorde con su propia filosofía: la potencia visual (quwwat al-basar) «se caracteriza por recibir los conceptos de los colores (ma 'āní l-alwān) abstraídos de la materia en tanto que conceptos particulares». ${ }^{31}$ Para Ibn Rušd el orden y la continuidad de los procesos naturales y físicos es fundamental. Por ello pone especial cuidado en describir todos los pasos de la percepción visual. En Taljīs Kitäb al-hāss wa-l-mahsūs, Ibn Rušd describe el proceso con una enorme fisicidad: la atmósfera ilumina el líquido ocular y éste ilumina la retícula interior; el ojo está formado por una sucesión de retículas que preservan el sentido común, es decir, el alma, y entran en contacto con ella. Los colores llegan hasta el alma, primero, por la luz que los activa, luego por el medio atmosférico que los lleva hasta el líquido ocular y las sucesivas retículas que los conducen hasta el sentido común, que está tras la última retícula y percibe las formas sensibles. ${ }^{32}$ El fenómeno de la visión se presenta con mucha mayor complejidad que las demás percepciones. La percepción del color requiere de la presencia de la luz. Para él, la luz es completamente incorpórea, pero pertenece al mundo físico: es «la perfección de lo diáfano». Ibn Rušd adopta una teoría intermedia para explicar la visión del color: el color es una mezcla de un cuerpo transparente, el fuego, con otro no transparente, la tierra, por lo que «el color es una especie de luz», pero sólo alcanza su perfección con la luz que recibe de fuera y lo potencia. ${ }^{33} \mathrm{La}$ luz es el agente de la visión. Para que la visión sea óptima, la luz ha de ser moderada (mu tadil), pues la excesiva intensidad y la escasez son perjudiciales para la visión. Este principio filosófico, ético y estético aristotélico se introduce también en la psicología averroísta, aunque Ibn al-Haytam, comentador también de De anima, le dio un desarrollo mayor y lo tomó como premisa fundamental para su teoría de la percepción estética. Para Ibn Rušd todas las combinaciones de colores se originan a partir de los cuatro elementos, dos de los cuales son transparentes (el agua y el aire), otro es luminoso (el fuego) y el cuarto es opaco y oscuro (la tierra). La variedad cromática depende de la diferente transparencia de los elementos constitutivos de la materia y de la diversa intensidad de la luz. Esto explica, a su parecer, la formación del arco iris, es decir, por la iluminación de un soporte variable, como las nubes. Otros sabios musulmanes, como Ibn Hazm y los ópticos, explicaron el fenómeno introduciendo el concepto de la refracción de la luz y experiencias concretas para demostrarlo. El color blanco surge de la mezcla del fuego en estado puro con el aire, mientras que el negro lo hace a partir de la mezcla del fuego oscuro con elementos de menor transparencia como la tierra. Los colores intermedios, que forman todo el espectro cromático entre el blanco y el negro, dependen de la mayor o menor diafanidad de los cuerpos. El blanco y el negro pueden considerar-

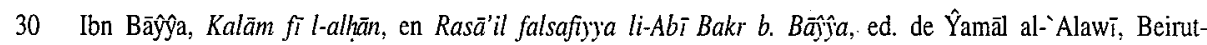
Casablanca, 1983, pp. 82-83.

31 Ibn Rušd, Taljīs Kitäb al-nafs, p. 43.

32 Ibn Rušd detalla su fisiología del ojo y de la visión en al-Kulliyyāt fíl-țibb; existe traducción castellana de esta parte de la obra en M. Cruz Hernández, Abü-l-Walīd Ibn Rušd (Averroes): vida, obra, pensamiento, influencia, Córdoba, Caja de Ahorros de Córdoba, pp. 333-340.

33 Ibn Rušd, Taljiș Kitäb al-nafs, pp. 47-48. 
se como los elementos constitutivos de todos los colores (istaqisät al-alwän). En su Gran comentario a la Metafísica define la blancura como el color que dispersa la vista y la negrura como el color que la reúne; entre ambos contrarios, el resto de los colores están compuestos de una porción de uno y otro color en cantidades variables, $y$, por ello, son ilimitados en la naturaleza. Asume, también, la idea de Aristóteles de que el blanco es la unidad primordial con la que se componen todos los colores, mientras que el negro es la ausencia de blanco, $y$, entre ambos, se forma todo el espectro cromático, aunque cada color tiene identidad propia y posee un lugar gradual en dicho espectro. Paralelamente, los sabores derivan de lo amargo y lo dulce, y varían al variar la intensidad de ambos o su grado de humedad.

\subsection{El placer de los sentidos}

Ibn Ḩazm no aborda, en sentido estricto, este tema, sino que alude a él en diversos pasajes de contendio moralista. Desde este punto de vista, los placeres sensoriales no están vedados, salvo que la Revelación se pronuncie en algún caso concreto, pero tampoco se deben buscar por sí mismos, puesto que son inferiores al placer intelectual: «El placer del intelectual con su discernimiento, del conocedor con su conocimiento, del sabio con su sabiduría y el placer de quien se esfuerza por Dios, son mayores que el placer de la comida, la bebida, la unión sexual, la ganancia, el juego y el que siente el mandatario con sus órdenes». ${ }^{34}$ Lo único que verdaderamente merece la pena es el Paraíso: «quien se alegra con la belleza de su voz debe saber que muchos pájaros cantan mejor y que los sonidos de las flautas son más placenteros y entretenidos que los suyos» ${ }^{35}$ Las artes, sea la poesía o las artes suntuarias, tienen como límite siempre, para Ibn Hazm, la incitación a la depravación o a los placeres superfluos. La pasión, que es reiteradamente combatida por el sabio cordobés, consiste en el anhelo compulsivo de placer y poder, e incide directamente en los fenómenos del conocimiento, del amor y de la percepción estética. Ibn Hazm es, a veces, más preciso: todos los placeres son transitorios, por lo que el sabio, aunque no renuncie a ellos, deberá abandonarlos cuando entorpezcan el camino de la Salvación. La prerrogativa del ser humano está en dominar con la razón sus apetitos, su deseo. Dentro del marco ético del islam, el uso de los placeres es lícito y positivo, como lo reitera Ibn Hazm en el Collar de la paloma. Se propone, como en Sócrates, la continencia y la moderación, pero se admite una amplia gama de placeres, tanto de los sentidos como intelectuales. Otros juristas, caso de lbn Taymiyya, fueron mucho más rigoristas y excluyentes en este campo. La unión amorosa es, para el alfaquí cordobés, la dicha más grande de este mundo, sólo superada por la dicha del Paraíso; todos los placeres del mundo caducan, pero, entretanto, la unión amorosa es vida renovada, es una «gran misericordia de Dios», ante la que no hay placer que se le equipare:

Ni la aparición del follaje de las plantas tras la lluvia caída, ni el brillo de las flores después de pasar las nubes con agua en la estación templada, ni el murmullo de las aguas que discurren entre ramas floridas, ni la hermosura de los blancos palacios cercados por verdes jardines, son mejores que la unión con el amado cuando te satisfacen sus caracteres, alabas sus 
dones naturales y sus cualidades se corresponden en belleza. Es algo que ni los retónicos pueden expresar, ni lo alcanza la oratoria de los más elocuentes. Ante ello se aturden los corazones y se enajena el entendimiento. ${ }^{36}$

Para Ibn Hazm, por otro lado, las formas sensibles estimulan la parte apetitiva del alma entreteniéndola en placeres sensuales que no son verdadero amor, sino sólo apetitos, como tampoco ahí está la auténtica belleża, que es ese «algo» o ese «brillo» que un alma encuentra en otra más allá de los accidentes formales. Pero esta aparente dualidad, típica del platonismo, entre mundo material y espiritual, se resuelve en Ibn Hazm con la dimensión sensible que da siempre al alma. Se trata de un alma que depende, precisamente, de esas percepciones sensoriales para, después, elevarse, si es un alma penetrante, hasta la belleza espiritual. Aquí habría que recordar los famosos grados de belleza establecidos por Ibn Hazm, pero me conformaré con aludir a la dimensión sensorial de su vocabulario: 1) dulzura (halāwa), delicadeza de encantos, finura de ademanes, o sea, la aceptación por parte del alma de los accidentes de la forma aunque ésta carezca de cualidades manifiestas; 2) la corrección (qawām): es la hermosura $(\hat{y} a m \bar{a} l)$ de cada cualidad por separado, aunque a menudo quien es hermoso en sus cualidades tomadas aisladamente puede tener un semblante frío y no ser ni salado, ni bello, ni espléndido, ni dulce; 3) esplendor (raw'a): brillo de los mienbros externos, es también la viveza y la nobleza; 4) belleza (husn): es indefinible, carece de sinónimos, es como un brillo (Ǐ̌rāq) que inclina los corazones hacia sí; es el súmmum de la belleza; y 5) la sal (maläha): es la reunión de varias de estas categorías. ${ }^{37}$ La polisemia e indefinición de esta terminología estética se suple con vocablos de la percepción sensible, del gusto, en unos casos, y, sobre todo, de la visión, mayoritariamente relacionados, en el caso de Ibn Hazm, con las ideas de armonía corporal y luminosidad. Finalmente, el vocabulario estético linda y se completa con el ético. ${ }^{38}$

Ibn Sidā de Murcia definía también una larga serie de términos estéticos en al-Mujașas, donde, además de los consabidos étimos relativos a la blancura, el brillo y la claridad, recurriría asimismo a términos de perfección, y a otros más sensoriales relativos al tacto, lo suave y lo blando, aunque son de nuevo las definiciones visuales las predominantes, como en tantos retóricos y sabios del islam: esplendor, contraste cromático, blancura, la pureza y brillo del color, buena complexión, y algunas cualidades espirituales: gracia, donaire. La hermosura espléndida ( $\left.a l \cdot b a h a \bar{a}^{\prime}\right)$-decía Ibn Sĩdā - es el buen y magnífico panorama que colma la vista. ${ }^{39}$

Ibn Bāŷỹa expone su teoría del placer en la Carta de adiós, compuesta para explicar a un amigo el método de unión con el intelecto adquirido y acceder al Fin Último y la Felicidad Suprema. El placer en sí mismo es una de las tres finalidades humanas posibles, junto a la de satisfacer a Dios y la de buscar sólo el prestigio social y la ostentación. Los placeres pueden ser: 1) sen-

36 Ibn Hazm, Tawq al-hamāma (XX), en Rasä'il Ibn Hazm, I, pp. 180-181.

37 Ibn Hazm, Risäla fi mudāuät al-nufüs, pp. 375-376.

38 En cuanto al amor, las fomas bellas son el primer peldaño hacia el mismo, pero el alma sólo superará el nivel inferior de los apetitos para acceder al verdadero amor cuando sea capaz de descubrir tras las formas y caracteres semejantes a los suyos en el alma contemplada. El amor es un fenómeno de reconocimiento y confimación espirtual entre dos almas, cuya relación se produce a través de los sentidos y donde la belleza física es un magnífico punto de partida para alcanzar el amor verdadero, precisamente por la fuerte atracción que las formas ejercen sobre las almas.

39 Ibn Sida, al-Mujassaș, Beirut, Manšrürä al-Maktab liw-Tiyâra wa-1-Tawzi, s.a., II, pp. 151-157, 
sorial, que es bajo y vil; 2) dominio, honores y gloria mundana y 3) placer de la ciencia, dependiendo su nobleza del rango de la ciencia en cuestión. Los placeres sensoriales son unánimemente rechazados como inferiores por todos, mientras que el segundo grupo presenta discusión. El placer superior será el de la Teología. La fruición cognoscitiva es doble: a) la que acompaña al deseo de conocimiento y b) el deseo fruto del saber, del que participan cuatro sentidos corporales, pero, sobre todo, la vista y el oído:

Cuando vemos un bello espectáculo, sentimos el placer (iltid $\underline{d} \bar{d}$ ) ) de verlo sin que vaya precedido de dolor alguno. Lo mismo sucede con el oído, aunque en la audición pueden concurrir placer y dolor, como cuando escuchamos canciones tristes. Un análisis detallado de este tema no se corresponde con lo que aquí nos ocupa. ${ }^{40}$

Lástima que no se ocupara de este tema de percepción estética, aunque en este pasaje sitúa la fruición estética en el ámbito del conocimiento y como placer elevado al que no precede ningún estado de ansiedad o dolor, sino que se inicia con una percepción sensorial y se disfruta de modo directo como puro conocimiento ( $\mathrm{i} / \mathrm{m}$ ). Lo que a él le interesa es resaltar la idea de que todo placer es siempre derivado y nunca ha de ser un fin en sí mismo. Incluso el placer cognoscitivo es un lujo que se nos da por añadidura. Los placeres se dividen, pues, en físicos y espirituales: 1) los físi$\cos$ ( $a$ l-laddat al-tabĩ ijyya), producto de objetos tangibles, como el calor, el frío, la comida, la bebida y el coito; su intensidad es variable y carecen de continuidad, pues van precedidos necesariamente de sus contrarios: el hambre, la sed, etc. 2) los inteligibles. (ma ' qülät) se clasifican a su vez en: a) intelectual, placer producto del saber, b) de la fantasía: cuentos, bromas o chistes, y c) el deleite de los sentidos (iltidäd al-hiss), caso de la vista, el oído, etc. Conviene subrayar que Ibn Bāŷya incluye los placeres sensoriales, de la vista y el oído sobre todo, entre los placeres intelectuales, porque representan ya cierta abtracción respecto a la materia y a los demás placeres físicos. En resumen, cabe hablar de una estética sensorial perteneciente al ámbito de los inteligibles, cuya fruición sería continua, es decir, unitaria y permanente, pero sólo mientras perdura la relación perceptiva entre receptor y objeto contemplado, toda vez que no deja de ser una estética dependiente de los sentidos. Frente a dicha estética sensorial, Ibn Bâŷŷa apunta hacia una estética contemplativa, cuya experiencia ha de ser plenamente continua e inefable. Sólo el entendimiento adquirido está capacitado para el deleite perpetuo. El alma irracional apegada al mundo físico no es simple y no puede mantenerse en un mismo estado, por lo que siente dolor o placer a veces hasta con una misma cosa. El alma separada de la materia, simple, entra por el conocimiento en un estado inefable de majestad, nobleza, esplendor y gozo. Es el nivel superior luminoso e intemporal, la Felicidad Suprema. Nos encontramos en una transición gradual desde el movimiento a la inmovilidad, de lo diverso a lo único, de lo opaco y manchado a lo luminoso, de lo material a lo inmaterial, de la ignorancia al conocimiento, de los fines inferiores al Fin Supremo. Pero, a diferencia de al-Gazālī, no hay oposición entre mundo físico y espiritual en la que un sexto sentido da el salto gustativamente al saber, sino que el sujeto humano es descrito con una compleja psicología ligada al mundo mate-

40 Ibn Bāŷŷa, «La 'Carta de Adiós' de Avempace» (Risälat al-wadā’), ed. y tr. de Asín Palacios, Al-Andalus, VIII, 1943, p. 23 (tr. p. 57). 
rial que lo hace agente, no sólo de la producción artística, sino también de la percepción estética sensorial, y de su inmediata abstracción y elevación hasta la unión con el Intelecto Agente, quien, al mismo tiempo, ilumina al solitario filósofo y le proporciona el disfrute del mundo ideal superior.

En cuanto a Ibn Rušd, nos da su definición del placer y de la fruición artística en su comentario a la Retórica de Aristóteles Comienza definiendo el placer de este modo:

El placer consiste en una alteración hacia un estado que sucede súbitamente a partir de una sensación natural de una cosa percibida, es decir, cuando lo percibido es natural para el perceptor. $^{41}$

El placer consiste en la satisfación de los deseos, es decir, de los apetitos racionales e irracionales. Los apetitos irracionales son los apetitos corporales no tamizados por la reflexión intelectual, y van desde la comida o el coito hasta los aromas agradables. Los apetitos del oído y la vista tienen, para Ibn Rušd, cierta racionalidad, son más elevados que los meramente corporales, porque uno está relacionado con la palabra oída y, el otro, con la escritura y la gesticulación de que se vale la oratoria. A la fantasía (tajy $l$ l) le corresponde también un deleite, el de rememorar las cosas agradables pretéritas e imaginar las que podremos disfrutar. Lo novedoso es otra fuente de placer, que la tratadística literaria árabe tuvo muy presente, aunque Ibn Rušd apenas se limitó a mencionarlo. En cuanto a la fruición estética, que se sitúa en el área de la imaginación, a medio camino entre las percepciones sensibles y la cogitatio, Ibn Rušd la explica por comparación -y en relación-con el placer del aprendizaje: «la representación imaginaria (tajy $\bar{i} l$ ) es placentera (ladī $d$ ) por el parecido que tiene con la enseñanza ( ta $^{\circ}$ İm) $\gg,{ }^{42}$ y lo explica con la siguiente argumentación: el deseo de aprender tiene su causa en la propia estima y en la ajena, y deriva del anhelo (tašawwuq) de perfección $(k a m a \bar{l})$; la consecución de una perfección es siempre placentera, y, con el aprendizaje se obtiene una perfección, de la misma manera que con la imitación y la representación imaginarias obtenemos una perfección cuando conocemos una relación oculta entre las cosas; es el fenómeno del reconocimiento que lleva aparejado el arte, y que para el gran comentarista de Aristóteles está en la base tanto del aprendizaje como de las artes imitativas:

La imitación y la enseñanza son placenteras, puesto que significan acceder a la relación existente entre las cosas. El conocimiento de dichas relaciones entre los seres es un anhelo connatural al ser humano, por lo que las semejanzas y los ejemplos son placenteros (...). El placer radica — concluye Ibn Rušd - en la percepción de la relación existente entre unas cosas y otras en el mundo. ${ }^{43}$

La dimensión puramente formal del arte queda una vez más en suspenso en favor del contenido: dicho placer — dice sin ambigüedad Ibn Rušd — «no viene generado porque la forma imitada (al-șina al-mušabbaha) sea bella o fea (hasana aw qabiha), sino porque en la imitación se produ-

41 Ibn Rušd, Taljị̦ al-Jițāba, ed. de `Abd al-Rahmān Badawī, Kuwait-Beirut, Wikālat al-Matbưāt-Dār al-Qalam, s. a, p. 89.

42 Ibn Rušd, o.c., p. 96.

43 Ibn Rušd, o.c., p. 97. 
ce cierta analogía y un reconocimiento de lo más recóndito (al-muqāysa wa-ta rî́fal-ajfà), es decir, de lo desconocido sobre la base de una similitud con lo ya conocido». ${ }^{44}$ Con esto, Ibn Rušd trata de acotar, en el caso de las artes, la dimensión sensible, que él mismo establece para todo placer, en favor de su dimensión ética, apartándose así de otros falāsifa, de buena parte de la crítica literaria árabe clásica y, de manera especialmente intensa, de aquel otro comentarista de la Poética y de De anima que fue el gran óptico medieval Ibn al-Hayṭam, uno de los más interesantes precursores de la Estética. Mientras que al-Fārābī e Ibn Sīnā, por ejemplo, concedían, dentro de la falsafa, posibilidades a la función lúdica de las artes, Ibn Rušd no tarda en esgrimir textos coránicos y en remitir los elementos de asombro y maravilla $\left(t a^{`} a \hat{y} \hat{y} u b\right)$ a la intención ética del poeta, para acabar, de nuevo, justificando la fruición poética por la fuerza que tiene para transmitir valores éticos:

No se pretende con el arte de los poetas — dice Ibn Rušd en su Taljị Kitāb al-ši r-producir cualquier tipo de placer, sino que con dicho arte se pretende obtener placer sugiriendo imaginariamente las virtudes ( $f a d \bar{a}^{\prime} i l$ ), que es el deleite que corresponde al arte del panegírico. ${ }^{45}$

La poética de Ibn Rušd recorre los temas de Aristóteles, pero se vierte de manera sistemática en el molde de là ética coránica y se le asigna una clara función pedagógica, dentro de su proyecto filosófico general, que trata de activar las facultades racionales humanas, de un lado, y, de otro, recuperar la autenticidad del mensaje revelado, como las dos grandes columnas que nos guían en el camino único de la Verdad.

Desde la retórica y la poética árabes, Hāāzim al-Qarțāyāann̄̄ (1211-1285) concede un lugar fundamental a los sentidos. La poesía, y el arte en general, consiste en una transmutación de la realidad a través de la forma y en su transmisión al receptor. Para que dicha transmutación sea efectiva y bella, la obra deberá ejecutarse según los principios de armonía de las partes y del todo, de la precisión en la ejecución técnica y de un distanciamiento de la realidad a través de las leyes del contraste cromático, el destello luminoso y el reflejo especular. El placer estético que de todo ello se deriva, se percibe como asombro y maravilla, sobre todo si existen elementos novedosos y se sabe tocar la fibra del receptor buscando lo insólito y las profundas inquietudes humanas. Hâazim relaciona siempre las artes del oído y las de la mirada:

La relación entre la representación imaginaria $($ tajy $\bar{l}$ ) y su elocución imitativa con el alma y el oído es como la relación existente respecto al ojo entre la transparencia del cristal y su contenido, al revelar el cristal el secreto que encierra, o similar también a las figuras de velas encendidas y las frondas verdes con blancas flores que se reflejan sobre láminas de agua. La visión de las imágenes de estas cosas es diferente a la contemplación real de las mismas, puesto que contemplarlas reflejadas en el agua es menos habitual para el ser humano que verlas en la realidad (...) De igual modo, la imitación de una cosa por medio de otra, es más rara que imitarla con sus propios caracteres. Es más novedosa e imprevista. ${ }^{46}$

44 Ibn Rušd, o.c., p. 96.

45 Ibn Rušd, Taljiș Kitāb al-ši 'r, ed. de Ch. H. Butterworth y `Abd al-Rahmān Harīdī, El Cairo, al-Hay’a alMișriyya al-'Āmma li-l-Kitäb, 1986, pp. 87-88.

46 Hāzim al-Qartâŷannī, Minhạ̄̂̂al-bulagãa', ed. de Muhammad al-Ḥabīb Ibn al-Jūŷa, Beirut, Dār al-Garb, 1986, pp. 128-129. 
El problema ya no es la verdad, ni la transmisión de valores éticos como en Ibn Rušd, sino la creación de una obra bella que atraiga al receptor basándose en los aspectos sensoriales innatos que caracterizan la psicología humana. Su idea de mímesis, por tanto, no es simplemente la reproducción realista de la realidad, sino que se trata de una reelaboración de la misma no enteramente naturalista, sino introduciendo los ełementos mencionados de la estética más característica de la cultura árabe, que es eminentemente sensorial, es decir, la estética de la luz, el contraste cromático, el reflejo, la armonía y la perfecta ejecución. Y, si en las artes de la geometría artística o la caligrafía estos parámetros parecen claros y evidentes, Hăãim se ocupará con detalle de explorar las posibilidades de aplicarlos a la composición poética, lo que hace en una prolija, minuciosa y ambiciosa investigación de todos los componentes de la casida para conseguir la armonía total de la misma y su institución como obra de arte luminosa, innovadora y perfecta.

Ibn Jaldūn (1332-1407), hablando sobre el arte del canto, entiende que los sonidos armónicos producen una sensación de placer aprovechando que «el oído disfruta percibiendo los sonidos armónicos». ${ }^{47}$ Así, define el placer (ladda) en general como «la percepción de lo conveniente; lo sensible es una cualidad, por lo que cuando ésta se percibe armónica y convenientemente resulta agradable, pero cuando es incompatible y disarmónica entonces resulta penosa». ${ }^{48}$ Esta definición de placer, que coincide con la de los Hermanos de la Pureza, aunque sin la dimensión metafísica y cósmica que ellos le daban en sus Rasāill, así como con la de al-Rāzíl ${ }^{-49}$ y, casi con las mismas palabras, con la de Ibn Sīnā ${ }^{50}$ la hace extensible Ibn Jaldūn a las percepciones de cado uno de los sentidos:

En los sabores, lo conveniente (mulä'im) es aquello cuya cualidad armoniza con la naturaleza del sentido del gusto; lo mismo sucede con lo conveniente en el tacto y en los aromas: se trata de aquello que armoniza ( $n \bar{a} s a b a$ ) la naturaleza del espíritu cordial ( $r \bar{u} h$ qalbì) y humoroso, al que el órgano sensorial (al-hāssa) Ie transmite la percepción. Por esto, los arrayanes y las flores aromáticas son el más bello aroma (ậsan al-rā'ihăt) y el más conveniente (mulā'im) que existe para el espíritu, debido a que en él predomina el calor (harāra) que es el mismo que tiene la naturaleza del espíritu cordial. ${ }^{51}$

47 Ibn Jaldūn, al-Muqaddima, Beirut, Dār al-Kitāb al-Lubnaniyya, 1960, V-32, p. 759.

48 Ibn Jaldūn, o.c., V-32, p. 760.

49 Abū Bakr Ibn Zakariyya al-Rāzī (863-932): el placer de los sonidos y de los bellos rostros se debe a la armonía y el orden internos de los objetos tenidos como placenteros; el placer consiste en la conservación del equilibrio natural del cuerpo y la salud. Para al-Rāzī, como para al-Färābī, «el juego, la alegría y el placer» son válidos para rehacerse y reanudar los esfuerzos serios (Ibn Zakariyya al-Rāzī, Ras à'il falsafiyya, Beirut, Dār al-Āfāq al-Ŷadīda, 1979³ , p. 62 y pp. 139-164).

50 «El placer (ladd $\underline{a}$ ) consiste en la percepción de lo conveniente (idräk al-mulä'im)... -dice Ibn Sinā-, siendo lo conveniente la perfección de la esencia de una cosa dada y la perfección de su acción» (Risāla Adhawiyya fi amr al-

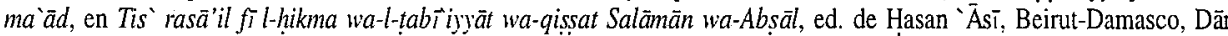
Qābis, 1986, p. 112). Esto se aplica tanto a los placeres sensoriales como a los de la imaginación, donde radica la fruición estética, y a los espirituales. Luego, llama la atención sobre los placeres intelectuales, contra la opinión del vulgo de que el placer es sólo sensorial. Al-Fārābī también ligaba el placer a la perfección del objeto y a la mayor precisión en la percepción del objeto; el arte tiene, además, una dimensión lúdica y placentera, es juego (la i ib) y, como tal, antesala y descanso de los asuntos serios, como dijimos en la nota anterior (cf. al-Fārāōi, Kitāb al-mūisìqà al-kabīr, El Cairo, Dār al-Kātib al-'Arabī, 1967, pp. 1184-1185).

51 Ibn Jaldūn, al-Muqaddima, V-32, p. 760. 
La conveniencia es la adecuación interna de los objetos percibidos y, al mismo tiempo, como una adecuación concreta dependiente de las características propias de cada uno de los sentidos respecto al centro de la percepción, que Ibn Jaldūn denomina, el espíritu cordial, con lo que aleja la idea de percepción armónica del intelecto y la acerca al corazón y a la esfera de los humores. ${ }^{52} \mathrm{La}$ creación poética era para Ibn Jaldūn también producto del gusto, dawq, que definía como una sensibilidad interna especial e innata que se desarrolla como el hábito (malaka), diciendo que recibe dicho nombre al coincidir en la lengua ambas sensibilidades, es decir, el paladar y el lenguaje.

Interesa ver cómo explica Ibn Jaldūn este fenómeno en el caso de las percepciones visuales y acústicas, donde, partiendo de una idea similar a la de Ibn al-Haytam sobre la belleza como proporción armónica de las formas visuales, le da, sin embargo, una explicación de carácter platónico:

En cuanto a las percepciones visuales y acústica, la conveniencia de ellas se encuentra en la proporción armónica (tanäsub) en la disposición tanto de sus figuras (aškāl) como de sus cualidades (kayfiyyāt), con lo que su conformidad y conveniencia es mucho mayor respecto al alma. Si el objeto visible tiene unas formas (ašk $\bar{a} l)$ y perfiles (tajạt $\bar{t} t$ ) armónicos de acuerdo con su materia constitutiva, y sin salirse de la proporción y disposición perfectas exigidas por su materia particular, que es lo que se entiende por la belleza ( $\hat{y} a m a \ddot{l})$ y la hermosura (husn) de toda percepción sensible, entonces armonizará con el alma perceptora y ésta se deleitará (taltad $\underline{d}$ ) con la percepción de lo conveniente. ${ }^{53}$

Este concepto de belleza aúna la pura sensibilidad con la idea platónica de la unión primordial. El ideal de la belleza sensible se encuentra en el cuerpo humano, que es donde se dan los dos niveles de armonía que definen el concepto de belleza de Ibn Jaldūn: la armonía de la figura externa y su voz, que es una armonía sensorial y objetiva, y la sintonía amorosa que siente el alma al rememorar la unidad primordial con el otro ser, que es una armonía espiritual y subjetiva sustentada en la percepción sensible de las formas del ser amado. Toda persona ama innatamente con pasión la hermosura y, en la audición, la hermosura consiste en que los sonidos sean armónicos.

\section{SENSIBILIDAD Y CONTEMPLACIÓN BEATÍFICA}

El itinerario del conocimiento del autodidacto de Ibn Tufayl (ca. 1110-1185) parte de la observación minuciosa del mundo sensible para elevarse progresivamente hasta la contemplación del mundo divino. El conocimiento superior depende del gusto (dawq) y no de la percepción sensorial ni de la reflexión intelectual. Ibn Țufayl contrapone la «percepción de los teóricos (idrak ahl alnazar), de los falāsifa, a la «percepción de los místicos» (idrāk ahl al-walāja o mutașawwifün). El solitario de Ibn Țufayl comienza por dar testimonio de la belleza y perfección del mundo sensible intuyendo el Poder y la Sabiduría del Creador y tomando la decisión de buscar el conocimiento de

52 Al-Gazāī sitúa también en el corazón el sexto sentido que posibilita el conocimiento estético y espiritual trascendiendo el mundo sensible.

53 Ibn Jaldūn, al-Muqaddima, V-32, p. 760. 
la fuente de dicha perfección, es decir, conociendo contemplativamente los atributos del Creador. En línea con la filosofía de al-Gazālī, Ibn Țufayl insiste en que la percepción sensorial se circunscribe al ámbito del mundo material y que ni siquiera la fantasía supera las formas del mundo tridimensional, por lo que el conocimiento y la contemplación de la divinidad precisan una sensibilidad diferente. En la percepción sensorial nuestros sentidos pasan de potencia a acto relacionándose con el objeto percibido, conociéndolo, añorándolo cuando vuelve a estar en potencia. Es un fenómeno que se produce, sobre todo, en el caso de las percepciones visuales (mubsarāt) y «en la medida en que el objeto percibido sea más pleno (atamm), más esplendoroso (abhà) y más bello (ahsan), el deseo (šawq) hacia el mismo será mayor y el dolor sentido por su pérdida será también mayor». ${ }^{54}$ Como otros muchos pensadores, Ibn Tufayl entiende que la pérdida de la visión comporta un dolor superior a la pérdida del olfato, puesto que las cosas percibidas visualmente son, a su juicio, «más perfectas (atamm) y bellas (ahsan) que las que percibe el olfato». ${ }^{55} \mathrm{~A}$ la contemplación estética sensorial, cuyo punto culminante se encuentra en la vista como órgano privilegiado, idea, como hemos dicho, extendida en el pensamiento andalusí y árabe en general, le acompaña una fruición y un deseo naturales hacia el objeto contemplado que depende del grado de esplendor y belleza del mismo, por lo que, siguiendo con esta dualidad, la contemplación metafísica comportará un deleite ilimitado y sublime en correspondencia con la trascendencia del objeto en cuestión:

Aquello que sea infinitamente perfecto (kamāl) y alcance el ápice de la belleza (husn), la hermosura ( $\hat{y} a m \bar{a} l$ ) y el esplendor (bahā ), que esté por encima de toda perfección, esplendor y belleza, y que toda perfección, belleza, esplendor, hermosura procedan y emanen de ello, provocará necesariamente, en quien deje de percibirlo después de conocerlo, un dolor infinito, al igual que quien lo perciba permanentemente, sentirá un placer (ladd $\underline{d} a$ ) ininterrumpido, una dicha (gibta) superior y un goce (bahya) y una alegría (surta $\left.\bar{a}^{*}\right)$ infinitos. ${ }^{56}$

Su teoría del placer es, por tanto, eminentemente metafísica. Se trata de la contemplación de los atributos de Perfección, Grandeza, Belleza, etc., del Ser Necesario, que conlleva un estado de absoluto e infinito deleite (ladda). Así lo dice en otro pasaje:

Vio que la esencia de esta esfera tenía una perfección, esplendor y belleza (husn) tan grandes que no podían ser descritos verbalmente, tan sutiles que no podían ser tratados con letras o sonidos, y la vio, en el ápice del goce ( $l a \underline{d} \underline{d} a$ ), la alegría, la dicha y el júbilo, gracias a su contemplación de la Esencia del Verdadero. ${ }^{57}$

A pesar de que Ibn Tufayl sitúa la percepción sensible, o mejor, el reconocimiento sensitivoracional del mundo sensible como punto de partida del itinerario de accesis contemplativa, considera, del mismo modo que al-Gäzalī, pero no así Ibn 'Arabī, que las percepciones sensibles (mahsiūs $\bar{a} t$ ), al igual que la imaginación (jay'äl), son un velo y un obstáculo para la contemplación

54 Ibn Ṭufayl, Hạy b. Yaqzān, ed. de Fārūq Sa`d, Beirut, Dār al-Āfāq al-Ŷadīda, 1980², p. 181.

55 Ibn Tufayl, o.c., p. 181.

56 Ibn Țufayl, o.c., p. 181.

57 Ibn Tufayl, o.c., p. 211. 
del Ser Necesario, que es una contemplación pura y exclusivamente gustativa. Tal contemplación es indescriptible, inconcebible para nuestro estado corporal habitual, es, dice Ibn Tufayl, como tratar de conocer el sabor de los colores, si el negro es dulce o amargo, por ejemplo. El mundo sensible es, por tanto, como la sombra del mundo divino, el cual se mantiene, a diferencia del sufismo de Ibn 'Arabī, completamente al margen de la materia. Por ello, su sensibilidad se ve limitada al primer reconocimiento e intuición de la perfección de la creación y del Creador, y no se requiere una teoría de la sensibilidad, puesto que el conocimiento auténtico es el gustativo y los sentidos lo interfieren. El mundo superior es decrito en término inefables de perfección, unidad, luminosidad, gratuidad y permanencia que transcienden y escapan a la percepción sensorial.

Aunque Ibn Jaldün no desarrolla en extenso su teoría de la percepción y del conocimiento, considero que habría que situarla en línea con la de su estimado imām al-Gazālī. Ibn Jaldūn define el alma perceptora (al-nafs al-mudrika) distinguiendo entre sensibilidad externa e interna, según un escalonamiento ascendente de las facultades que va desde los sentidos hasta la cogitativa, pasando por el sentido común, la estimativa, la imaginativa y la memoria. Estas facultades van ordenadas desde la parte frontal del cerebro, con el sentido común, hasta la posterior, donde se sitúa la memoria; el pensamiento (fikr) gobierna el conjunto desde el centro y se ocupa de la reflexión y la intelección. Sin embargo, Ibn Jaldūn atribuye enseguida la percepción, la intelección y el placer estético a cierto humor cordial y corona su teoría del conocimiento con el irfän o conocimiento místico, contemplativo, de al-Gazālī. De este modo, divide las almas humanas en tres grupos: 1) inferior, ligadas al mundo sensible, con la estimativa y la imaginativa como potencias superiores, 2) intelectual, que permite la contemplación interior (al-musăhadāt al-bătininiyya) y el éxtasis (wiŷdān); es el nivel de los predilectos de Dios y el de quienes acceden al limbo (barzaj); y 3) superación total de la naturaleza humana, corporal y espiritual o mundo angelical donde se disfruta de la mayor proximidad a Dios. Ibn Jaldūn apela al gusto (dawq) y a la contemplación (mušăhada) como nanera de conocer las concordancias (munäsaba) de lo oculto más allá de la lógica, donde deja entrever una estética contemplativa al modo de al-Gazälī.

\section{SOBRE LOS SENTIDOS EN EL SUFISMO DE IBN`ARABİ}

Asín Palacios entroncó el pensamiento de Ibn `Arabī con Ibn Masarra de Córdoba (883-931), quien, tempranamente, buscó en al-Andalus una nueva experiencia vital y filosófica que, en contradicción con la intolerancia del mälikismo imperante, buscaría en el neoplatonismo y en una revisión profunda del Islam los elementos de un nuevo discurso basado esencialmente en el Unitarismo universal y el iluminismo. La idea del Uno de Plotino, presente también en la teoría de la Materia espiritual como emanación primera del Uno del pseudo-Empédocles, pasó a través de Ibn Masarra a Ibn 'Arabi conjuntando de manera paradógica, pero profunda, las ideas de trascendencia absoluta de la Esencia divina y la teofanía o manifestación de Dios en todas y cada una de las cosas. La concepción de un Dios como luz suprasensible, Superior y absolutamente Bueno que reúne el Bien, el Saber y la Belleza se encuentra en los fragmentos textuales que conservamos de Ibn Masarra, así como la confrontación entre belleza espiritual y sensible, todo lo cual nos remite, según Asín Palacios, al pseudoEmpédocles árabe e, incluso, hasta el propio Empédocles (s. V a. C.). Sin embargo, justo es decir que Ibn `Arabī da un giro muy personal, amplio y profundo a toda esta trayectoria cognoscitiva. 


\subsection{Teoría del conocimiento gnóstico Akbarī}

El conocimiento es para Ibn 'Arabī un esfuerzo por reunir lo visible y lo invisible, para dar una dimensión existencial a lo imaginario y, viceversa, por imaginar la existencia en ese inmenso espacio intermedio, barzajt, en el que se reúne lo existencial y lo divino, lo patente y lo oculto, el ser y el símbolo, el Verdadero y la creación. Por ello, para Ibn 'Arabī la Imaginación trasciende las teorias del conocimiento clásicas en la cultura árabe islámica, y más específicamente el psicologismo de la falsafa antes comentado, que consideraba la imaginación como una más de las potencias anímicas, para situar en ella nada más y nada menos que el secreto y la realidad del Mundo y definirla como la mayor de las creaciones divinas: «El Poder Divino no ha creado ningún ser más inmenso que la Imaginación», escribió en Futühtăt. ${ }^{58}$ Contra la hermenéutica tradicional, desde Ibn Rušd hasta el fiqh, pasando por el Katäm, el sufismo de Ibn `Arabī trata de fundar una exégesis total y profunda al margen de las luchas sectarias uniendo la iluminación sufí con el conjunto de la percepción humana y con el viaje místico. Su intento traslada el lenguaje de su espacio social habitual a un espacio ontológico. Las exégesis convertidas en poder destruyen la unidad profunda entre ser y lenguaje, la unidad del mundo. El sufí trata de recuperar esa unidad perdida eliminando el poder del yo que conoce y sumergiéndose en el lenguaje de la formas simbólicas existenciales que expresa la relación del ser humano con la Existencia. Frente al lenguaje cerrado de la ortodoxia, Ibn 'Arabī instaura el lenguaje del símbolo siempre abierto y renovable gracias a la Imaginación, eternamente creativa e inggotable. Frente al mundo estático y ordenado según las leyes de la causalidad de Ibn Rušd, el mundo de Ibn `Arabī se concibe en una perpetua transformación sobre una misma Unidad de fondo.

Sensibilidad: este esquema de la médula del pensamiento Akbarí tiene su repercusión en su teoría de la sensibilidad y del conocimiento, que puede explicarse a partir de su concepto de kašf, desvelamiento o iluminación. mística, en la que se unifica y transforma el mundo de las percepciones sensibles con el de los conceptos de estructura simbólica, que están detrás del mundo y en los que es preciso internarse. Dios «es el que habla por cada forma, no en cada forma, es lo visto por todo ojo y lo escuchado por todo oído», advierte Ibn `Arabi ${ }^{59} \mathrm{Al}$ contrario que en la falsafa y el kalām, la percepción sensible no consiste para Ibn ‘Arabĩ en la aprehensión de los datos externos con el fin de alimentar el intelecto, sino en un movimiento inverso que va desde el interior del yo del sufí hacia el mundo exterior. Al-Šayj al-Akbar se sitúa al margen de la estructura piramidal del conocimiento de la falsafa, que, como hemos visto, parte de los sentidos para elevarse hasta los procesos cognoscitivos de las facultades intermedias y superiores, y se remite a su idea de Existencia (wulŷuld) y a su concepción de la realidad como una permanente multiplicación de manifestaciones divinas ( $(a \hat{a j a l l i y y} \bar{a}$ ). Lo sensorial (mahsüs) es, en este contexto, un conjunto de imágenes y figuras existenciales que ocultan los secretos y los significados divinos, por lo que la percepción sensible sólo tiene valor para el sufí cuando se explica en relación con dichas formas existenciales. Los sentidos no son, sin embargo, un impedimento, sino que se alían a la visión interior (bașira) y la Imaginación (jayäl) para descubrir los significados ocultos, es decir, para llevar a efec- 
to el desvelamiento $(k a s \tilde{f})$. A los sentidos se les encomienda, por tanto, una función creativa, no pasiva. La visión mística del mundo es, como han dicho algunos (Sulaymān al- Atțār, por ejemplo), una visión artística precisamente por esta creatividad, no porque sea contemplativa. Para Ibn 'Arabi todos los sentidos actúan al mismo nivel, no los gradúa en cuanto a superioridad perceptiva o cognoscitiva. Todos nos acercan por igual al mundo y estimulan al suff a emplear sus facultades superiores para desvelar los secretos de la naturaleza. Todos los sentidos incitan a la Imaginación, por lo que la percepción sensorial se funde con ella y es de por sí percepción imaginaria, en el sentido existencial que da a este concepto.

Cogitativa: En el tratado sobre el amor que Ibn 'Arabī incluye en Futühät, expone un curioso diálogo entre la cogitativa y el alma en el que subraya las limitaciones de la cogitativa, cuya única función se reduce a permitir que el alma reconozca que tiene un Creador, ${ }^{60}$ pero es incapaz de conocer la Señoría del Hacedor, con lo que la «racionalidad» se agota en el reconocimiento del Creador -como en Ibn Hazam o Ibn Rušd, por ejemplo-, y no puede acceder a la comprensión del mundo imaginal de las teofanías y de la Unidad. Al hablar sobre el conocimiento de los atributos divinos, Ibn 'Arabĩ decía que Dios creó el intelecto (aql) en el alma racional (al-năfs al-nătiqqa) como «contraposición al apetito físico» con la finalidad de discernir las normas reveladas. Dios mismo enseña, afirma el gran suff́ murciano, que Él creó la cogitativa para guiar y dominar los seres, pero, siempre, a las órdenes de la Imaginación, que opera, en el ser humano, con el concurso de las facultades sensoriales (al-quwà al-hissiyya) y de la potencia imaginadora (al-quwwa al-mușawwira) encargada de reelaborar las percepciones comunes de los sentidos individuales. ${ }^{61}$ La cogitativa, a parte de confirmar que Dios es la Esencia divina, está abocada, sin embargo, al error hermenéutico: la interpretación de los atributos divinos que ofrece el intelecto siempre es contraria a la Revelación. Los filósofos especulativos (ahl al-nazar) aducen continuamente pruebas racionales sobre la Esencia divina, pero nunca coinciden en sus argumentos, y siempre niegan la Revelación en alguno de sus extremos, o caen en el tašbih (antropomorfismo) o se aferran al tanzih (absoluta trascendencia divina). Esta aparente contradicción deja atónito al intelecto. Ibn `Arabī despoja al intelecto de su capacidad cognoscitiva, pero no cae en el dogmatismo de otros sufies beligerentes frontalmente contra la razón:

En la creación está la esencia del Verdadero para aquél que tiene ojos, como en el Verdadero se encuentra la esencia de la creación para aquél que tiene intelecto. Pero, si tienes ojos e intelecto, no verás más que la esencia de una sola cosa abarcándolo todo. ${ }^{62}$

A lo que renuncia es a toda metafísica que ordene piramidalmente la divinidad, el ser humano y el mundo. Puede decirse que toda su obra pugna por deshacer ese orden y sustituirlo por una filosofía vital de la Unidad Existencial. Su mayor crítica va dirigida contra la imposición de la razón como instrumento universal y definitivo, puesto que cada filosofo interpreta a Dios de modo dife-

60 Ibn 'Arabi, o.c., II, p. 330.

61 Ibn 'Arabï, o.c., II, p. 319.

62 Ibn 'Arabī, Kitäb al-ma 'rifa, mas'la 94, ed. de Saĩd 'Abd al-Fattäh, París-Beirut, Dār al-Mutanabbī, 1993, p. 86. 
rente. En lugar del intelecto, el órgano cognoscitivo por excelencia del sufismo es el corazón $(q a b)^{63}$ y el extenso campo de la Imaginación (jayal), lo que se pone particularmente de manifiesto en el terreno de la estética, donde el intelecto nunca puede contemplar la Belleza divina. No por casualidad, al tratar sobre el Nombre divino al-Ŷamil, el Bello, Ibn 'Arabi termína concentrándose en los límites cognoscitivos del intelecto. Se precisa de un saber de lo oculto, del Misterio, infralingüístico (tahta l-nutq), que para él pertenece a todos los saberes del gusto (dawq). Es el ámbito del corazón y la Imaginación, el verdadero ámbito de conocimiento y la realidad auténtica para Ibn 'Arabi. La Imaginación es, en suma, el espacio en el que se resuelven las contradicciones, en el que se impone la unidad profunda entre tanzih y tašbih y en el que se contemplan la Perfección, Majestad y Belleza divinas que rigen el Mundo.

José Miguel Puerta Vílchez

Biblioteca Municipal 18650 Dúrcal (Granada)

63 En Mawāqi al-nuŷum (cf, ed. de Muhammad Badr al-Dïn al-Na`sānī, [El Cairo], Matbàat al-Sa äda, 1907, p. 145), Ibn 'Arabi liga los carismas de los órganos corporales, en cuya descripción destacan los propios de la visión y el ofdo, a los carismas del corazón. Tanto a los órganos como al corazón se les atribuyen funciones de desvelamiento y de conocimiento simbólico y visionario más allá de la realidad sensible sometida a las leyes de la causalidad; los grados superiores de iluminación tienen su sede última en el corazón. 